\title{
The importance of Anopheles albitarsis $E$ and An. darlingi in human malaria transmission in Boa Vista, state of Roraima, Brazil
}

\author{
Marinete Marins Póvoa, Raimundo Tadeu Lessa de Souza, \\ Raimundo Nonato da Luz Lacerda, Edvaldo Santa Rosa, Deocleciano Galiza, \\ James Rodrigues de Souza*, Robert A Wirt**, Carl D Schlichting***, Jan E Conn****/+
}

Instituto Evandro Chagas, Ananindeua, PA, Brasil *Secretaria Municipal de Saúde, Departamento de Epidemiologia, Boa Vista, RR, Brasil **Department of Entomology, Centers for Disease Control and Prevention, Atlanta, GA, US ***Department of Ecology and Evolutionary Biology, University of Connecticut, Storrs, CT, US ****Griffin Laboratory, Wadsworth Center, New York State Department of Health, Slingerlands, NY 12159, US

In several districts of Boa Vista, state of Roraima, Brazil we found Anopheles (Nyssorhynchus) albitarsis E to be the primary vector of human malaria parasites, and during 2001-2002 it was significantly more abundant than An. darlingi $(p<0.001)$. Other species sampled were An. (Nys.) braziliensis, An. (Ano.) peryassui, An. (Nys.) nuneztovari, An. (Nys.) oswaldoi s.l., and An. (Nys.) triannulatus. As determined by the ELISA technique An. darlingi had a higher overall infection rate (2.1\%) compared with An. albitarsis E (1.2\%). However, a marginally higher proportion of An. albitarsis $E$ was infected with Plasmodium vivax compared with An. darlingi, and the An. albitarsis $E$ biting index was also much higher. These results suggest the importance of An. albitarsis E in malaria transmission in a savannah ecoregion of northern Amazonian Brazil, and reconfirm the importance of An. darlingi even if at lower abundance.

Key words: Anopheles albitarsis E - Anopheles darlingi - malaria - Roraima - Brazil

Although the importance of Anopheles darlingi in malaria transmission in Amazonia is undiminished (Tadei et al. 1998, Rosa-Freitas et al. 1998, Lounibos \& Conn 2000), the biological and epidemiological diversity of other Anopheles species involved in regional or local transmission suggests that a variety of control strategies will be needed to effectively reduce the incidence of malaria. Among those species also responsible for malaria transmission are members of the An. (Nys.) albitarsis LynchArribalzaga species complex (Conn et al. 2002). This complex consists of four species, three formally named, another identified by random amplified polymorphic DNApolymerase chain reaction (RAPD-PCR) (An. albitarsis s.s., An. deaneorum, An. marajoara, and An. albitarsis B respectively; Wilkerson et al. 1995a,b), and an additional putative species closely related to An. marajoara, An. albitarsis E (Lehr et al. 2005, but see Wilkerson et al. 2005). Two species are considered to be malaria vectors, $A n$. deaneorum (based on experimental infection, Klein et al. 1991a,b) and An. marajoara (based on field data including ELISA to test for malaria parasites, Conn et al. 2002). An. marajoara appears to be the primary malaria vector in Serra do Navio, state of Amapá (Póvoa et al. 2000b); as

Financial support: National Institutes of Health, US (grants TW009951 and R01 AI54139 to JEC); Instituto Evandro Chagas, Belém, state of Pará; Secretaria Municipal de Saúde, Departamento de Epidemiologia, Boa Vista, state of Roraima +Corresponding author: jconn@wadsworth.org

Received 14 October 2005

Accepted 21 February 2006 well as in Boa Vista, state of Roraima (Silva-Vasconcelos et al. 2002). An. marajoara has been identified as the main malaria vector in the port city of Santana and in periurban sections of the city of Macapá in the state of Amapá by Conn et al. (2002), and confirmed as An. marajoara by sequences of the mtDNA COI gene (Lehr 2003). In Serra do Navio, Amapá, An. albitarsis s.l. has also been identified as An. marajoara using the mtDNA COI gene (Lehr 2003). These data indicate that $A n$. marajoara is a significant regional vector in northeastern Amazonian Brazil, and it is important to know more about its local distribution and role in malaria transmission throughout Amazonian Brazil.

The taxonomic status of An. albitarsis $\mathrm{E}$ is not yet clearly resolved. It is readily identified as monophyletic using appropriate outgroups and phylogenetic approaches such as maximum parsimony (MP), maximum likelihood (ML) and Bayesian analysis when analyzed using complete sequences of the mitochondrial DNA (mtDNA) COI gene (Lehr et al. 2005). On the other hand, partial sequences of nuclear genes (ribosomal DNA ITS2 and D2) and mtDNA genes (COI and ND4) using some of the same sample localities, and some of the same analyses, could not detect this taxon (Wilkerson et al. 2005). The new molecular key to distinguish among members of the Albitarsis complex, based on ribosomal DNA internal transcribed spacer 2 (ITS2) differences (Li \& Wilkerson 2005), cannot distinguish An. albitarsis E from An. marajoara because their ITS2 sequences are identical. It is evident that additional analyses are needed, using independent data sources (Rubinoff \& Holland 2005), and extensive geographical samples, to resolve the taxonomic status of An. albitarsis E

Approximately $99 \%$ of the malaria cases in Brazil occur in the Amazon region (PAHO 2002). The state of 
Roraima, which persists in having one of the highest annual parasitic indices (API; number of cases/1000) for malaria in Brazil (Silva-Vasconcelos et al. 2002) is the most northern Brazilian state, sharing international borders with Guyana and Venezuela. The capital of Roraima, Boa Vista, is in the savannah ecoregion of Rubio-Palis and Zimmerman (1997) and is characterized by: a long rainy season (April-November), a short dry season (DecemberMarch), a mean annual temperature of $27.8^{\circ} \mathrm{C}$, and a mean rainfall of $429 \mathrm{~mm}$ (Silva-Vasconcelos et al. 2002).

Our objectives were to identify which species of $A n$. albitarsis s.l. is responsible for malaria transmission in Boa Vista and to extend the initial studies by SilvaVasconcelos et al. (2002) by examining anophelines from several additional endemic malaria localities there.

\section{MATERIALS AND METHODS}

Study sites - For continuity with and an extension of the study by Silva-Vasconcelos et al. (2002) we collected in two localities, 13 de Setembro (along the Rio Branco) and Caranã (along the Rio Cauamé). We chose four additional localities (Cauamé, Jardim da Copaiba, Caçari, and Distrito Industrial) where malaria cases had recently (20002001) been reported to the Secretaria Municipal de Saúde in Boa Vista.

Adult collection and identification - Mosquitoes were collected between 18:30-21:00 h, coincident with the peak biting time of the majority of anophelines found in Boa Vista as reported by Silva-Vasconcelos et al. (2002). There were seven collection periods: March, May, and September of 2001, and March, June, August, and November of 2002. To detect infected mosquitoes that might be biting at other than crepuscular and post-crepuscular times (Voorham 2002) we added two 12-h collections at Jardim da Copaiba, one in August 2002 and one in April 2003. We collected primarily during the rainy season because there is a significant positive correlation between rainfall and malaria cases in Boa Vista (Silva-Vasconcelos et al. 2002). Informed consent was obtained from all collectors, and the Biosafety Committee at the Instituto Evandro Chagas in Belém, state of Pará, the Vermont Institutional Review Board, and New York State Department of Health Institutional Review Board approved the project. Mosquitoes were identified within $24 \mathrm{~h}$ using the taxonomic key of Deane et al. (1946). The samples of An. albitarsis s.l. were initially identified as An. marajoara based on RAPD banding patterns in Wilkerson et al. (1995a), but subsequently as An. albitarsis E based on the mtDNA COI gene sequence (Lehr et al. 2005). Biting indices (BI) were calculated by dividing the number of mosquitoes captured by the number of collectors and the number of hours they collected.

Malaria parasite identification - Each mosquito specimen was divided into two parts: the head and thorax were maintained dry for ELISA analysis and then processed using standard protocols (Wirtz et al. 1987, 1991, 1992) to detect Plasmodium (falciparum, malariae, vivax VK210, and vivax VK247); and the abdomens were preserved for molecular identification and DNA analysis. Anopheles species other than An. darlingi or An. mara- joara were analyzed by ELISA in pools of a maximum of five individuals (except in one case, Table I).

Data analysis - The variances for the data on abundances of An. darlingi and An. albitarsis $\mathrm{E}$ and the malaria parasites were too high to be transformed to meet the assumptions of normality or homoscedasticity. Therefore, all data were transformed to ranks and a Kruskal-Wallis analysis was performed with the following variables: total mosquitoes collected, total mosquitoes positive for $P$. falciparum and total mosquitoes positive for $P$. vivax (both variants were combined in all analyses). A separate analysis for $P$. malariae was not undertaken because the sample size was too small (see Table I). Class effects in the analysis were species, site, month, and their two-way interactions. Data from only four of the six localities (Jardim da Copaiba, Caçari, Caraña, and 13 de Setembro) were analyzed using Kruskal-Wallis because in the Distrito Industrial we did not detect An. darlingi, and in Cauamé after the first very dismal showing (March 2001, Table I) we failed to find either of our key target species.

The data from the 12-h collections at Jardim da Copaiba (Results and Figure) were not included in this analysis because of small sample size.

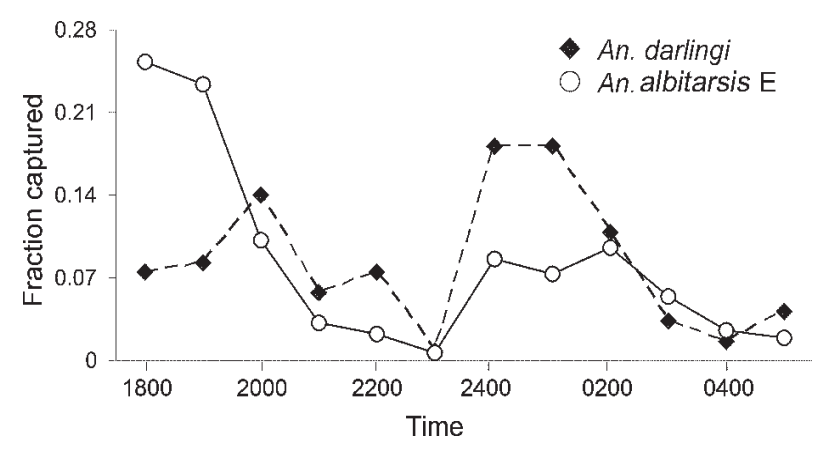

Fraction of captured Anopheles albitarsis E and An. darlingi by hour. August 2002, Jardim da Copaiba, Boa Vista, Roraima, Brazil.

\section{RESULTS}

We collected and identified 4673 mosquitoes using human landing catches in six districts in Boa Vista. The samples of An. albitarsis s.l. were identified as $A n$. albitarsis $\mathrm{E}$ using $\mathrm{COI}$ sequences (Lehr et al. 2005). An. albitarsis $\mathrm{E}$ was most abundant ( $80.9 \%$ ) followed by $A n$. darlingi (9.8\%), An. braziliensis (6.3\%), and An. peryassui (1.6\%). Each of An. nuneztovari, An. oswaldoi s.l., and An. triannulatus was detected at less than $1 \%$ (Table I). Significantly more $(P<0.001$; Table II) $A n$. albitarsis $\mathrm{E}$ were collected compared with An. darlingi and it is obvious from the abundance of An. albitarsis $\mathrm{E}$ attracted to humans (mean $=140.17$ versus mean of 15.9 for An. darlingi) that in Boa Vista this species is anthropophilic. The abundance of An. albitarsis $\mathrm{E}$ is also evident from the BI that range from 0.25-30.5, whereas for $A n$. darlingi the range is 0.03-6.5 (Table I). Despite these differences in mosquito abundance and biting rate, only marginally significantly more $(p=0.058)$ An. albitarsis $\mathrm{E}$ were infected with $P$. vivax compared with An. darlingi 
and there was no significant difference for $P$. falciparum (Table II). P. vivax (70.5\%, both variants) was the most common parasite detected in mosquitoes, followed by $P$. falciparum (27.3\%) and P. malariae (2.3\%).

There was a significant monthly difference (Table II) in total mosquito abundance between May 2001 (mean = $37.0)$ and June $2002($ mean $=168.3)$, although both are during the rainy season. Months also differed significantly for number of mosquitoes infected with $P$. falciparum, probably because there were no mosquitoes

\section{TABLE I}

Total number of Anopheles mosquitoes collected, biting index (BI), and number infected by collection date from several localities in Boa Vista, state of Roraima, Brazil, 2001-2002

\begin{tabular}{|c|c|c|c|c|c|c|c|c|c|c|c|c|}
\hline \multirow[b]{3}{*}{ Locality } & \multicolumn{10}{|c|}{ Species } & & \\
\hline & \multicolumn{6}{|c|}{ An. darlingi } & \multicolumn{6}{|c|}{ An. albitarsis $\mathrm{E}$} \\
\hline & $\mathrm{T}$ & BI & Pf & $\begin{array}{l}\text { VK } \\
210\end{array}$ & $\begin{array}{l}\text { VK } \\
247 \\
\end{array}$ & $\mathrm{Pm}$ & $\mathrm{T}$ & BI & Pf & $\begin{array}{l}\text { VK } \\
210 \\
\end{array}$ & $\begin{array}{l}\text { VK } \\
247\end{array}$ & $\mathrm{Pm}$ \\
\hline $\begin{array}{l}\text { Mar } 01 \\
13 \text { Setembro } \\
\text { Cauamé }^{b}\end{array}$ & $\begin{array}{l}1 \\
0\end{array}$ & 0.03 & 0 & 0 & 0 & 0 & $\begin{array}{r}22 \\
1\end{array}$ & $\begin{array}{l}0.56 \\
0.25\end{array}$ & $\begin{array}{l}2 \\
0\end{array}$ & $\begin{array}{l}1 \\
0\end{array}$ & $\begin{array}{l}0 \\
0\end{array}$ & $\begin{array}{l}0 \\
0\end{array}$ \\
\hline $\begin{array}{l}\text { May } 01 \\
13 \text { Setembro } \\
\text { D. Industrial } \\
\text { Jar. Copaiba } \\
\text { Caçari }^{c} \\
\text { Caraña }^{b}\end{array}$ & $\begin{array}{r}0 \\
0 \\
3 \\
12 \\
4\end{array}$ & $\begin{array}{l}0.2 \\
0.44 \\
0.25\end{array}$ & $\begin{array}{l}0 \\
0 \\
0\end{array}$ & $\begin{array}{l}0 \\
0 \\
1\end{array}$ & $\begin{array}{l}0 \\
0 \\
0\end{array}$ & $\begin{array}{l}0 \\
0 \\
0\end{array}$ & $\begin{array}{r}55 \\
44 \\
49 \\
105 \\
68\end{array}$ & $\begin{array}{l}4.4 \\
2.93 \\
3.27 \\
3.89 \\
4.25\end{array}$ & $\begin{array}{l}1 \\
0 \\
0 \\
0 \\
0\end{array}$ & $\begin{array}{l}2 \\
0 \\
1 \\
4 \\
1\end{array}$ & $\begin{array}{l}0 \\
0 \\
1 \\
1 \\
0\end{array}$ & $\begin{array}{l}0 \\
0 \\
0 \\
0 \\
0\end{array}$ \\
\hline $\begin{array}{l}\text { Sept. } 01 \\
13 \text { Setembro }{ }^{d} \\
\text { D. Industrial }{ }^{e} \\
\text { Jar. Copaiba }^{f} \\
\text { Caçari }{ }^{g} \\
\text { Caraña }^{h}\end{array}$ & $\begin{array}{r}2 \\
0 \\
1 \\
18 \\
23\end{array}$ & $\begin{array}{l}0.11 \\
\\
0.03 \\
0.41 \\
0.58\end{array}$ & $\begin{array}{l}0 \\
0 \\
0 \\
1\end{array}$ & $\begin{array}{l}0 \\
0 \\
1 \\
1\end{array}$ & $\begin{array}{l}0 \\
0 \\
0 \\
0\end{array}$ & $\begin{array}{l}0 \\
0 \\
0 \\
0\end{array}$ & $\begin{array}{r}239 \\
48 \\
184 \\
61 \\
24\end{array}$ & $\begin{array}{l}13.28 \\
3.0 \\
5.75 \\
1.39 \\
0.6\end{array}$ & $\begin{array}{l}2 \\
0 \\
2 \\
1 \\
0\end{array}$ & $\begin{array}{l}3 \\
0 \\
3 \\
1 \\
0\end{array}$ & $\begin{array}{l}0 \\
0 \\
0 \\
0 \\
0\end{array}$ & $\begin{array}{l}0 \\
0 \\
0 \\
0 \\
0\end{array}$ \\
\hline $\begin{array}{l}\text { Mar } 02 \\
13 \text { Setembro } \\
\text { Jar. Copaiba } \\
\text { Caçari } \\
\text { Caranã } \\
\text { D. Industrial }{ }^{j}\end{array}$ & $\begin{array}{l}0 \\
3 \\
0 \\
0 \\
0\end{array}$ & 0.75 & 0 & 0 & 0 & 0 & $\begin{array}{r}6 \\
15 \\
16 \\
4 \\
25\end{array}$ & $\begin{array}{l}1.5 \\
3.75 \\
0.76 \\
0.22 \\
2.08\end{array}$ & $\begin{array}{l}0 \\
0 \\
0 \\
0 \\
0\end{array}$ & $\begin{array}{l}0 \\
0 \\
0 \\
0 \\
0\end{array}$ & $\begin{array}{l}0 \\
0 \\
0 \\
0 \\
0\end{array}$ & $\begin{array}{l}0 \\
0 \\
0 \\
0 \\
0\end{array}$ \\
\hline $\begin{array}{l}\text { June } 02 \\
13 \text { Setembro } \\
{ }^{l} \\
\text { Jar. Copaiba }^{m} \\
\text { Caçari }{ }^{n} \\
\text { Caranã }^{h}\end{array}$ & $\begin{array}{r}2 \\
12 \\
4 \\
7\end{array}$ & $\begin{array}{l}0.08 \\
0.24 \\
0.5 \\
0.7\end{array}$ & $\begin{array}{l}0 \\
0 \\
0 \\
0\end{array}$ & $\begin{array}{l}0 \\
0 \\
0 \\
0\end{array}$ & $\begin{array}{l}0 \\
0 \\
0 \\
0\end{array}$ & $\begin{array}{l}0 \\
0 \\
0 \\
0\end{array}$ & $\begin{array}{r}295^{k} \\
558 \\
244 \\
224\end{array}$ & $\begin{array}{l}12.29 \\
11.16 \\
30.5 \\
22.4\end{array}$ & $\begin{array}{l}1 \\
0 \\
0 \\
1\end{array}$ & $\begin{array}{l}8 \\
0 \\
0 \\
0\end{array}$ & $\begin{array}{l}0 \\
0 \\
0 \\
0\end{array}$ & $\begin{array}{l}0 \\
0 \\
0 \\
1\end{array}$ \\
\hline $\begin{array}{l}\text { Aug } 02 \\
13 \text { Setembro }^{o} \\
\text { Jar. Copaiba }^{p} \\
\text { Caçari }^{s} \\
\text { Caranã }^{t}\end{array}$ & $\begin{array}{r}12 \\
85 \\
11 \\
0\end{array}$ & $\begin{array}{l}0.4 \\
1.7 \\
0.92\end{array}$ & $\begin{array}{l}0 \\
0 \\
0\end{array}$ & $\begin{array}{l}2 \\
0 \\
0\end{array}$ & $\begin{array}{l}0 \\
1 \\
0\end{array}$ & $\begin{array}{l}0 \\
0 \\
0\end{array}$ & $\begin{array}{r}162 \\
601 \\
29 \\
34\end{array}$ & $\begin{array}{c}5.4 \\
12.02 \\
2.42 \\
2.83\end{array}$ & $\begin{array}{l}0 \\
0 \\
0 \\
0\end{array}$ & $\begin{array}{c}1 \\
3^{q} \\
0 \\
1^{u}\end{array}$ & $\begin{array}{l}0 \\
0 \\
0 \\
0\end{array}$ & $\begin{array}{l}0 \\
0 \\
0 \\
0\end{array}$ \\
\hline $\begin{array}{l}\text { Nov } 02 \\
13 \text { Setembro }{ }^{v} \\
\text { Jar. Copaiba } \\
\text { Caçari }{ }^{w} \\
\text { Caranã }\end{array}$ & $\begin{array}{r}0 \\
0 \\
106 \\
76\end{array}$ & & 0 & 0 & 0 & 0 & $\begin{array}{r}7 \\
150 \\
129 \\
105\end{array}$ & $\begin{array}{c}0.88 \\
25.0 \\
8.06 \\
26.25\end{array}$ & $\begin{array}{l}0 \\
0 \\
0 \\
0\end{array}$ & $\begin{array}{l}0 \\
0 \\
0 \\
0\end{array}$ & $\begin{array}{l}0 \\
0 \\
0 \\
0\end{array}$ & $\begin{array}{l}0 \\
0 \\
0 \\
0\end{array}$ \\
\hline
\end{tabular}

T: total number of mosquitoes identified; Pf: P. falciparum; VK210: P. vivax VK210; VK247: P. vivax VK247; Pm: P. malariae. Additional mosquito species collected (below) were all negative for Plasmodium except where noted. $a: 1$ An. nuneztovari; $b: 1$ An. braziliensis; c: 24 An. braziliensis and 1 An. peryassui; d: 7 An.braziliensis; $e$ : 51 An. peryassui, 27 An. braziliensis, 1 An. nuneztovari and 1 An. triannulatus; f: 53 An. braziliensis, 10 An. peryassui, 1 An. triannulatus; g: 27 An. braziliensis; $h: 4$ An. braziliensis; j:1 An. peryassui; $k$ : all mosquitoes analyzed in pools of $\mathrm{n}=3 ; l: 12$ An. braziliensis; m: 38 An. braziliensis, 9 An. peryassui, 1 An. nuneztovari; $n$ : 8 An. braziliensis, 1 An. peryassui; o: 7 An. braziliensis, 4 An. nuneztovari, 2 An. oswaldoi s.l., and 1 An. triannulatus; $p$ : 30 An. braziliensis and 6 An. nuneztovari; $q$ : pool of $\mathrm{n}=5 ; r$ : 5 An. braziliensis and 1 An. nuneztovari; $s$ : 26 An. braziliensis (1 pool of $\mathrm{n}=7$ positive for Pv1); $t: 15$ An. braziliensis, 2 An. peryassui; $u$ : pool of $\mathrm{n}=6$ mosquitoes; $v$ : 1 An. braziliensis, 1 An. triannulatus; w: 8 An. braziliensis; $x$ : 3 An. braziliensis, 1 An. triannulatus; $y$ : these mosquitoes were not tested. All collections peridomestic from 18:00-21:00 h unless otherwise noted. 
collected that were infected with this malaria parasite in March 2002, August 2002, and November 2002.

The significance of the species-by-site interaction term in Table II indicates that mosquito abundance differed among sites for these two species. An. albitarsis E is at its highest frequency at Jardim da Copaiba, whereas An. darlingi shows its greatest abundance at Caçari. Similarly, the significant species-by-month interaction term demonstrates that among months, the patterns of each species' abundance differed. In this case, An. albitarsis $\mathrm{E}$ is most abundant in June 2002 and An. darlingi is most abundant in November 2002.

The two 12-h collections undertaken in 2002 and 2003 at Jardim da Copaiba demonstrate, at least for 2002 (Figure), that An. albitarsis $\mathrm{E}$ in this district bites predominately in the early evening, has a smaller peak between 12:00 and 03:00 h, but can bite throughout the night. An. braziliensis was collected in 2002 at $18-19 \mathrm{~h}(\mathrm{n}=2)$, 19-20 $\mathrm{h}(\mathrm{n}=1)$ and at 23-24 $\mathrm{h}(\mathrm{n}=2)$. In 2003 An. albitarsis E was uncommon (18-19 h, $\mathrm{n}=2 ; 19-20 \mathrm{~h}, \mathrm{n}=1)$ and $A n$. darling $i$ was collected in low numbers biting through the night $(18-19 \mathrm{~h}, \mathrm{n}=7 ; 19-20 \mathrm{~h}, \mathrm{n}=2 ; 20-21 \mathrm{~h}, \mathrm{n}=3 ; 21-22 \mathrm{~h}$, $\mathrm{n}=2 ; 22-23 \mathrm{~h}, \mathrm{n}=3 ; 23-24 \mathrm{~h}, \mathrm{n}=1 ; 24-01 \mathrm{~h}, \mathrm{n}=2 ; 01-02 \mathrm{~h}$, $\mathrm{n}=2 ; 02-03 \mathrm{~h}, \mathrm{n}=2 ; 04-05 \mathrm{~h}, \mathrm{n}=4)$. In both temporal collections, An. darlingi bit throughout the night, with a peak about the same time as An. albitarsis E's smaller peak (after midnight), and there was no discernible peak in 2003.

We detected infected mosquitoes during the 2002 collections: one An. darlingi infected with P. vivax VK210 and two An. albitarsis E, one infected with each of $P$. falciparum and $P$. vivax VK210. For all collections, all mosquito species collected were tested for Plasmodium but among the five additional species encountered, only one pool of $7 \mathrm{An}$. braziliensis was positive for $P$. vivax VK210 (Table I).

\section{DISCUSSION}

In terms of relative species abundance our data are congruent with those of Silva-Vasconcelos et al. (2002): An. albitarsis E (as An. albitarsis) > An. darlingi $>A n$. braziliensis $>$ An. peryassui $>$ An. nuneztovari. Their study also found a higher infection rate for An. darlingi in comparison with An albitarsis E, and the biting indices for An. darlingi are in the same range. However, the present study found higher biting indices for $A n$. albitarsis E in three localities: Caçari, Caranã, and Jardim da Copaiba. Although our 12-h collections were limited, they demonstrate the same pattern for An. darling $i$ and An. albitarsis E as found by Silva-Vasconcelos et al. (2002). $A n$. darling $i$ is known for its geographically variable patterns of biting activity (reviewed in Rosa-Freitas et al. 1992, Voorham 2002), resulting from either environmental variables, genetic differentiation, or possibly both. Interestingly, An. marajoara in Western Venezuela has a similar peak biting period as An. albitarsis E in Boa Vista (predominantly before midnight; Rubio-Palis \& Curtis 1992). We found a single pool of An. braziliensis infected with Plasmodium. Although a greater proportion of $A n$. braziliensis was infected in the study of Silva-Vasconcelos et al. (2002), in neither study, because of low abundance combined with low infectivity, does this species contribute significantly to malaria transmission.

Both studies found a much higher proportion of mosquitoes infected with $P$. vivax than $P$. falciparum, a reflection of the relative proportions of these two parasites in humans in Roraima (Chaves \& Rodrigues 2000), in other parts of the Amazon (e.g., Amapá, Conn et al. 2002; Pará, Póvoa et al. 2003) and throughout most endemic Neotropical countries (PAHO 2002). Both studies also found a higher proportion of mosquitoes infected with variant VK210 compared with variant VK247. In a recent study in three endemic malaria areas of Brazil, VK210 was associated with the highest parasitemia levels in humans compared with VK247 and $P$. vivax-like, although there was no differential response to chloroquine treatment among the three variants (Machado \& Póvoa 2000).

$P$. malariae was detected in only one mosquito ( $A n$. albitarsis E from Caranã), and in six individuals of $A n$. darlingi in the earlier study in Boa Vista (Silva-Vasconcelos et al. 2002) but ELISA slightly underestimates the overall prevalence of malaria parasites in anophelines because it is not as sensitive as ELISA-PCR (Póvoa et al. 2000a). Thick blood smears also underestimate the prevalence of $P$. malariae in humans (Scopel et al. 2004). These findings suggest that accurate diagnosis of $P$. malariae should be a higher priority because this parasite results in low, but significant levels of morbidity in humans

TABLE II

F-values from Kruskal-Wallis analysis of ranked data from six collections of Anopheles darlingi and An. albitarsis E at four locations in Boa Vista, Brazil

\begin{tabular}{|c|c|c|c|c|c|c|}
\hline \multirow[b]{3}{*}{$d f$} & \multicolumn{5}{|c|}{ Source } & \multirow[b]{2}{*}{ Month $\times$ Site } \\
\hline & Species & Month & Site & Species $\times$ Site & Species $\times$ Month & \\
\hline & 1 & 5 & 3 & 3 & 5 & 15 \\
\hline \multicolumn{7}{|l|}{ Traits } \\
\hline Total mosq. collected ${ }^{a}$ & $35.60^{c}$ & $5.13^{d}$ & $3.87^{e}$ & $4.03^{e}$ & $4.99^{d}$ & 1.89 \\
\hline \# falciparum & 3.79 & $2.95^{e}$ & 0.59 & 1.21 & 1.52 & 0.31 \\
\hline$\#$ vivax ${ }^{b}$ & $4.25^{e}$ & 0.98 & 0.73 & 1.01 & 0.92 & 0.81 \\
\hline
\end{tabular}

$a$ : this includes An. darlingi and An. albitarsis E; $b$ : this includes both $P$. vivax VK210 and $P$. vivax VK247; significance levels: $c: \mathrm{p}<0.001 ; d: \mathrm{p}<0.01 ; e: \mathrm{p}<0.05$. 
(Collins et al. 2004), there has been a recent resurgence in human cases in Pará (Póvoa et al. 2003) as well as in Suriname (PAHO 2002) and misdiagnosis may mean that the wrong antimalarial treatment is given (Scopel et al. 2004).

Because our collections identified An. albitarsis E exclusively of the four species in the An. albitarsis complex it is very likely that the mosquitoes referred to in SilvaVasconcelos et al. (2002) as An. albitarsis s.l. are also An. albitarsis E. Thus the present study confirms $A n$. albitarsis $\mathrm{E}$ as an important malaria vector, at a minimum in savannah habitat around Boa Vista. This finding does not diminish the importance of An. darlingi as the primary malaria vector in the Neotropics (Lounibos \& Conn 2000). In fact, in some localities An. darlingi has increased recently (Póvoa et al. 2003, Gil et al. 2003, Schoeler et al. 2003). The finding of the importance of An. albitarsis $\mathrm{E}$ in Boa Vista serves as a reminder that the heterogeneity of malaria vectors (reviewed in Lounibos \& Conn 2000) must be taken into account, whether in relation to integrated malaria control strategies that might be implemented (Alilo et al. 2004) or transgenic mosquitoes that could eventually be considered for release (Touré et al. 2004).

\section{ACKNOWLEDGEMENTS}

To RC Wilkerson and C Li at Walter Reed Army Institute for Research, Smithsonian Institute, Suitland, MD, and M Lehr, Department of Biology, University of Vermont for help in identification of samples of An. albitarsis s.l. from Boa Vista.

\section{REFERENCES}

Alilio MS, Bygbjerg IC, Breman JG 2004. Are multilateral malaria research and control programs the most successful? Lessons from the past 100 years in Africa. Am J Trop Med Hyg 71(Suppl.): 268-278.

Chaves SS, Rodrigues LC 2000. An initial examination of the epidemiology of malaria in the state of Roraima, in the Brazilian Amazon basin. Rev Inst Med Trop São Paulo 42: 269275.

Collins KM, Hochberg LP, Ryan PR, Collins WE, Wirtz RA, Ryan JR 2004. Quantification of Plasmodium malariae infection in mosquito vectors. Ann Trop Med Parasitol 98: 469-472.

Conn JE, Wilkerson RC, Segura NO, de Souza RTL, Schlichting CD, Wirtz RA, Póvoa MM 2002. Emergence of a new neotropical malaria vector facilitated by human migration and changes in land use. Am J Trop Med Hyg 66: 18-22.

Deane LM, Causey OR, Deane MP 1946. An illustrated key by adult female characteristics for identification of thirtyfive species of Anophelini from the Northeast and Amazon regions of Brazil, with notes on the malaria vectors (Diptera: Culicidae). Am J Hyg Mono Series 18: 1-18.

Gil LH, Alves FP, Zieler H, Salcedo JM, Durlacher RR, Cunha RP, Tada MS, Camargo LM, Camargo EP, Pereira-da-Silva LH 2003. Seasonal malaria transmission and variation of anopheline density in two distinct endemic areas in Brazilian Amazonia. J Med Entomol 40: 636-641.

Klein TA, Lima JB, Tada MS, Miller R 1991a. Comparative susceptibility of anopheline mosquitoes in Rondonia, Brazil to infection by Plasmodium vivax. Am J Trop Med Hyg 45: 463-470.
Klein TA, Lima JB, Tada MS 1991b. Comparative susceptibility of anopheline mosquitoes to Plasmodium falciparum in Rondonia, Brazil. Am J Trop Med Hyg 44: 598-603.

Lehr M 2003. Phylogenetics and Phylogeography of a Neotropical Anopheline Cryptic Species Complex, MSc Thesis, University of Vermont, US.

Lehr MA, Kilpatrick CW, Wilkerson RC, Conn JE 2005. Cryptic species in the Anopheles albitarsis (Diptera: Culicidae) complex: incongruence between RAPD-PCR identification and analysis of mtDNA COI sequences. Ann Ent Soc Amer 98: 908-917.

Li C, Wilkerson RC 2005. Identification of Anopheles (Nyssorhynchus) albitarsis complex species (Diptera: Culicidae) using rDNA internal transcribed spacer 2-based polymerase chain reaction primers. Mem Inst Oswaldo Cruz 100: 495500 .

Lounibos LP, Conn JE 2000. Malaria vector heterogeneity in South America. Am Entomol 46: 238-249.

Machado RL, Póvoa MM 2000. Distribution of Plasmodium vivax variants (VK210, VK247 and $P$. vivax-like) in three endemic areas of the Amazon region of Brazil and their correlation with chloroquine treatment. Trans $R$ Soc Trop Med Hyg 94: 377-381.

PAHO-Pan American Health Organization 2002. Status of malaria programs in the Americas. CSP26/INF/3.

Póvoa MM, Conn JE, Schlichting CD, Amaral JC, Segura MN, da Silva AN, dos Santos CC, Lacerda RN, de Souza RT, Galiza D, Santa Rosa EP, Wirtz RA 2003. Malaria vectors, epidemiology, and the re-emergence of Anopheles darling $i$ in Belém, Pará, Brazil. J Med Entomol 40: 379-386.

Póvoa MM, Machado RLD, Segura MNO, Vianna GMR, Vasconcelos AS, Conn JE 2000a. Infectivity of malaria vector mosquitoes: correlation of positivity between ELISA and PCR/ELISA tests. Trans R Soc Trop Med Hyg 94: 106107.

Póvoa MM, Wirtz RA, Lacerda RNL, Miles MA, Warhurst D 2000b. Malaria vectors in the municipality of Serra do Navio, state of Amapá, Amazon region, Brazil. Mem Inst Oswaldo Cruz 96: 179-184.

Rosa-Freitas MG, Broomfield G, Priestman A, Milligan JJM, Momen H, Molyneux DH 1992. Cuticular hydrocarbons, isoenzymes and behavior of three populations of Anopheles darlingi from Brazil. J Amer Mosq Contrl Assoc 8: 357366.

Rosa-Freitas MG, Lourenço-de-Oliveira R, de Carvalho-Pinto CJ, Flores-Mendoza C, Fernandes Silva-do-Nascimento T 1998. Anopheline species complexes in Brazil. Current knowledge of those related to malaria transmission. Mem Inst Oswaldo Cruz 93: 651-655.

Rubinoff D, Holland BS 2005. Between two extremes: mitochondrial DNA is neither the panacea nor the nemesis of phylogenetic and taxonomic inference. Syst Biol 54: 952961.

Rubio-Palis Y, Curtis CF 1992. Biting and resting behaviour of anophelines in western Venezuela and implications for control of malaria transmission. Med Vet Entomol 6: 325-334.

Rubio-Palis Y, Zimmermann RH 1997. Ecoregional classification of malaria vectors in the Neotropics. J Med Entomol 34: 499-510. 
Schoeler GB, Flores-Mendoza C, Fernandez R, Davila JR, Zyzak M 2003. Geographical distribution of Anopheles darlingi in the Amazon Basin region of Peru. J Am Mosq Contrl Assoc 19: 286-296.

Scopel KK, Fontes CJ, Nunes AC, Horta MF, Braga EM 2004. High prevalence of Plasmodium malariae infections in a Brazilian Amazon endemic area (Apiacas-Mato Grosso State) as detected by polymerase chain reaction. Acta Trop 90: 61-64.

Silva-Vasconcelos A, Kato MY, Mourao EN, de Souza RT, Lacerda RN, Sibajev A, Tsouris P, Póvoa MM, Momen H, Rosa-Freitas MG 2002. Biting indices, host-seeking activity and natural infection rates of anopheline species in Boa Vista, Roraima, Brazil from 1996 to 1998. Mem Inst Oswaldo Cruz 97: 151-161.

Tadei WP, Thatcher BT, Santos JMM, Scarpassa VM, Rodrigues IB, Rafael MS 1998. Ecologic observations on anopheline vectors of malaria in the Brazilian Amazon. Am J Trop Med Hyg 59: 325-335.

Touré YT, Oduola AM, Morel CM 2004. The Anopheles gambiae genome: next steps for malaria vector control. Trends Parasitol 20: 142-149.

Voorham J 2002. Intra-population plasticity of Anopheles darlingi's (Diptera, Culicidae) biting activity patterns in the state of Amapá, Brazil. Rev Saú Púb 36: 75-80.

Wilkerson RC, Foster PG, Li C, Sallum MAM 2005. Molecular phylogeny of the Neotropical Anopheles (Nyssorhynchus) albitarsis species complex (Diptera: Culicidae). Ann Ent Soc Amer 98: 918-925.

Wilkerson RC, Gaffigan TV, Lima JB 1995a. Identification of species related to Anopheles (Nyssorhynchus) albitarsis by random amplified polymorphic DNA-polymerase chain reaction (Diptera: Culicidae). Mem Inst Oswaldo Cruz 90: 721-732.

Wilkerson RC, Parsons TJ, Klein TA, Gaffigan TV, Bergo E, Consolim J 1995b. Diagnosis by random amplified polymorphic DNA polymerase chain reaction of four cryptic species related to Anopheles (Nyssorhynchus) albitarsis (Diptera: Culicidae) from Paraguay, Argentina, and Brazil. J Med Entomol 32: 697-704.

Wirtz RA, Charoenvit Y, Burkot TR, Esser KM, Beaudoin RL, Collins WE, Andre RG 1991. Evaluation of monoclonal antibodies against Plasmodium vivax sporozoites for ELISA development. Med Vet Entomol 5: 17-22.

Wirtz RA, Sattabonkgot J, Hall T, Burkot TR, Rosenberg R 1992. Development and evaluation of an enzyme-linked immunosorbent assay for Plasmodium vivax-VK247 sporozoites. J Med Entomol 29: 854-857.

Wirtz RA, Zavala F, Charoenvit Y, Campbell GH, Burkot TR, Schneider I, Esser KM, Beaudoin RL, Andre RG 1987. Comparative testing of monoclonal antibodies against Plasmodium falciparum sporozoites for ELISA development. Bull WHO 65: 39-45. 